\title{
O exílio liberal no Cone Sul da América de 1820: o caso de João Soares Lisboa em Buenos Aires (1822-1823)
}

\author{
Paula Botafogo Caricchio Ferreira ${ }^{1}$
}

Recibido: 24 de junio de 2020 / Aceptado: 14 de septiembre de 2020

Resumo. O texto analisa as redes de comunicação e a cultura política vivenciadas por João Soares Lisboa e outros exilados no Cone Sul, uma região militarizada e de fronteiras indeterminadas entre o Império do Brasil e as repúblicas hispano-americanas recém-independentes, nos anos de 1822-1823, a partir de Buenos Aires. Reconhecido na historiografia como o redator mais radical e, por vezes, republicano da província fluminense, após ter sido acusado de "conluio republicano" na primeira devassa política do império do Brasil (1822), João Soares Lisboa foi intimado pelo governo a deixar o Brasil e proibido de continuar na redação do Correio do Rio de Janeiro, através do qual protagonizara a politização do processo de independência do Brasil. Em novembro de 1822, embarcou clandestinamente para Buenos Aires, onde se exilou até o início de 1823. Sua experiência hispano-americana de exílio foi decisiva para a sua condenação e a absolvição de todos os outros réus, como Joaquim Gonçalves Ledo, demarcando a rearticulação do jogo político e constituindo um ponto de viragem na política do Império do Brasil. Neste sentido, o exílio é analisado como trânsito cultural, com sua construção de fronteiras e redes imaginárias, e aquisição de experiências e olhares sobre o "outro". Ademais, era um mecanismo da política liberal, uma espécie de modo de fazer político utilizado sobretudo por redatores. Mais tarde, o exílio integrou a memória histórica das trajetórias desses exilados como um elemento que as qualificava, por vezes, de radicais, em outras, como exemplos de percursos históricos de moderação constitucional.

Palavras-chave: Imprensa; Independências na América; exílio; liberalismo; siglo XIX.

\section{[en] Liberal Exiles in the Southern Cone of America in the 1820: the case of João Soares Lisboa in Buenos Aires (1822-1823)}

\begin{abstract}
This article examines communications networks and political culture, focusing on journalist João Soares Lisboa in Buenos Aires and other exiles in the Sourthern Cone, a militarized region with undetermined borders between the Brazilian Empire and the recently independent Spanish-American republics in the years 1822 to 1823 . Historically recognized as the most radical journalist in the Province of Río de Janeiro, Soares Lisboa was accused of "republican confabulation" in the first judicial and political investigation of the Brazilian Empire (1822) and was forced to leave the country. Likewise, the government prohibited him from working in the editorial office of the Correio do Rio de Janeiro newspaper, where he played a leading role in the politicization of the Brazilian independence process. In November 1822 he embarked clandestinely to Buenos Aires, where he went into exile until early 1823. His Spanish-American exile was a decisive factor in his condemnation and in the absolution of all others accused, such as Joaquim Gonçalves Ledo; it also defined the rearticulation of the political game, constituting a crucial moment in the politics of the Brazilian Empire. In this regard, exile is analyzed as a cultural transition, with the construction of imaginary boundaries and networks, as well as the

1 Pesquisadora de pós-doutorado com bolsa FAPESP no Departamento de História da Universidade de São Paulo, Laboratório de Estudos sobre o Brasil e o Sistema Mundial (Lab-Mundi-USP) [Brasil].

E-mail: paula.botafogo@gmail.com
\end{abstract}


acquisition of experiences and viewpoints on the "other"; also as a mechanism of liberal politics and as a form of doing politics, employed mainly by journalists. Later on, exile became a part of the historical memory of these exiles as a factor that at times served to qualify them as radicals and, at other times, as examples of historical trajectories of constitutional moderation.

Keywords: Press; Independence in America; Exile; Liberalism; 20th Century.

Sumario. 1. O exílio liberal na América. 2. O exílio de João Soares Lisboa em Buenos Aires. 3. O Correio do Rio de Janeiro no Cone Sul da América. 4. Republicano e Liberal? 5. O exílio como mecanismo da política liberal 6. Considerações Finais 7. Referências Bibliográficas.

Cómo citar: Carrichio Ferreira, P. B. (2021) "O exílio liberal no Cone Sul da América de 1820: o caso de João Soares Lisboa em Buenos Aires (1822-1823)", en Revista Complutense de Historia de América 47, 67-88.

\section{O exílio liberal na América}

Durante o Antigo Regime, o desterro era uma das principais punições aos criminosos. No século XIX, o degredo foi juridicamente desvinculado do exílio ${ }^{2}$. Os exilados participavam de redes de "migraciones políticas transfronterizas y a menudo transoceánicas" que interconectavam amplos setores das elites políticas e intelectuais ibero-americanas e articulavam as Revoluções Atlânticas, sendo assim fundamentais à construção do primeiro liberalismo na América. Neste sentido, Javier Fernández Sebastián destaca os poucos trabalhos biográficos existentes, considerando-se a suma importância de acompanhar as pistas fragmentadas destas redes. Ademais, adverte que se deve perseguir o trânsito de homens menos conhecidos que, para ele, foram capitais na politização e disseminação de conceitos políticos entre espaços singulares da Ibero-América, apropriados durante a primeira metade do século XIX a serviço de objetivos políticos ${ }^{3}$.

A ressignificação da tradição de desterro tornou-se uma prática comum aos liberais, que passaram a valorizar e universalizar as expressões de suas experiências. Os exilados pensavam-se integrantes da nação mesmo fora dos limites de seu território, compreendiam as suas fronteiras definidas por uma invocação moral e política que não se restringia à geografia propriamente $\operatorname{dita}^{4}$. Ao mesmo tempo, para eles, o exílio podia ser uma moeda de troca para posteriormente ocupar um lugar no poder instituído ${ }^{5}$. Além disto, particularmente no caso dos redatores, o exílio era uma possibilidade de continuar sua oposição ao governo em segurança, demonstrando capacidade de ação, comunicação e organização e sendo uma situação, inclusive, preferível em certos momentos de maior tensão política ou de risco de prisão ${ }^{6}$.

Neste sentido, é possível identificar, grosso modo, alguns elementos que conferem certa unidade às experiências dos exilados liberais no final do século XVIII e início do XIX. Primeiramente, a participação fundamental dos comerciantes para a manutenção destes homens no exílio através de incentivo, financiamento e circulação dos seus impressos -como jornais, panfletos e opúsculos- tornando-os, muitas

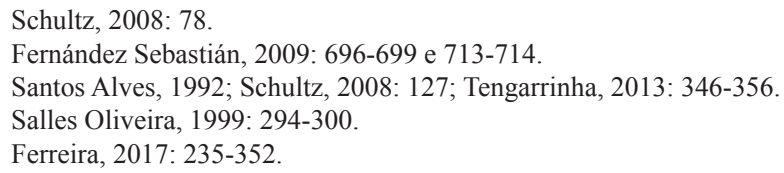


vezes, a expressão pública de seus próprios anseios ${ }^{7}$. Em segundo lugar, o exílio proporcionava um trânsito cultural e político aos exilados que lhes permitia maior liberdade de expressão e de crítica ao poder como focos de oposição ao governo, o que não significava que estivessem livres de retaliação. Contudo, tinham um maior espaço de manobra. Além disto, o exílio trazia novos olhares sobre o outro através de leituras e vivências que permitiam, em seu conjunto, alimentar visões de possibilidades políticas inovadoras, sobretudo em um momento de efervescência e profundas transformações políticas no bojo das recentes independências na América. Terceiro, o exílio marcou a memória da trajetória dos exilados. Ele integrava a memória histórica das trajetórias destes e as qualificava, por vezes, de radicais, em outras, como exemplos de percursos históricos de moderação constitucional. Deste modo, funcionava como mecanismo de política liberal, um modo do fazer político ${ }^{8}$.

Particularmente para os exilados na América, as narrativas sobre suas trajetórias, ao mesmo tempo em que contribuíam para eram também afetadas pela construção discursiva de uma dicotomia entre a monarquia luso-americana e as repúblicas hispano-americanas. Esta oposição abarcava a inevitabilidade dos caminhos políticos a serem percorridos nas porções da América e definia, de um lado, repúblicas marcadas por caos, anarquia e guerra e, de outro, a monarquia, considerada uma via moderada e mais saudável politicamente, sinônimo de unidade, harmonia e estabilidade 9 . Diante das guerras de independência hispano-americanas, pelo menos até 1821, as trocas de experiências com o Brasil eram mal vistas e deveriam ser evitadas para que não se repetisse o quadro de desordem, guerra civil e fragmentação observado na América espanhola. A partir desta data, a experiência hispano-americana assumiu contornos virtuosos e positivos, tornando-se um paradigma propositivo por considerar a independência uma alternativa viável para a manutenção de interesses conservadores ${ }^{10}$. De toda maneira, essa dicotomia definia um lócus de moderação para discursos, ideias, conceitos, posicionamentos políticos e mesmo trajetórias. Elegia um determinado projeto de Estado e nação do Brasil em detrimento de outros que eram, por isto, qualificados pejorativamente de radicais e republicanos, à maneira do que os hispano-americanos independentistas estabeleceram, tal como imaginado por João Soares Lisboa. Importante destacar que, na época, esta construção foi produzida e disseminada em impressos, tais como jornais, proclamações e discursos, e que se tratava de um período com uma proliferação e disseminação até então inédita de periódicos. Além disto, ganhou repercussão na memória histórica sobre a Independência do Brasil, por exemplo, em autores como Varnhagen ${ }^{11}$.

Desde as guerras de independência hispano-americanas de 1810, as Provincias Unidas en Sud America, que declarariam sua independência da Espanha em 1816, viviam um período marcado por crise e instabilidade, fragmentação política e territorial e uma crescente violência e militarização da política ${ }^{12}$. Estes elementos alimentavam o paradigma negativo de desordem, anarquia e guerra associado às repúblicas

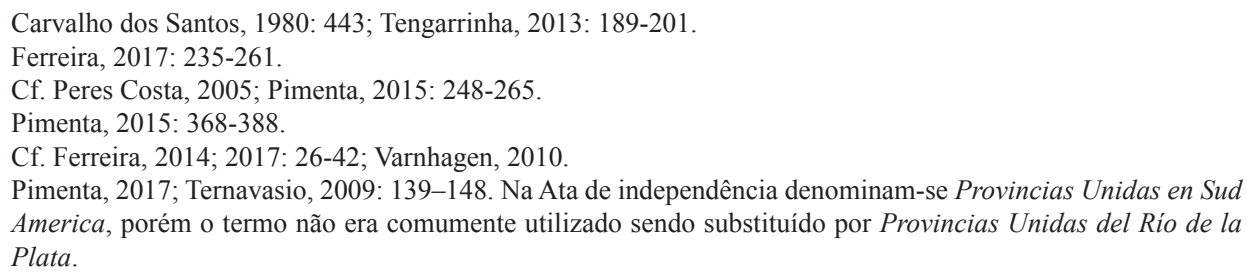


hispano-americanas. No início de 1820, Buenos Aires foi palco, primeiro, da renúncia do general José Rondeau, de orientação centralista e diretor supremo do Estado das Províncias Unidas e, em seguida, da dissolução do Congresso Nacional. No final daquele ano, formou-se uma Junta de Representantes que disputava com o Cabildo de Buenos Aires o controle do novo Estado provincial. A historiografia tradicional denominou este período "anarquia do ano 20" e Jorge Myers o caracteriza como uma "guerra de facciones sin cuartel", em referência à sucessão de governos efêmeros no período ${ }^{13}$. Por sua vez, Marcela Ternavasio afirma que o governo de Buenos Aires vivia uma dupla crise. Uma interna, de conflitos entre projetos unitários e federalistas e a ocupação da cidade portenha pelas montoneras do interior, grosso modo, de disputa entre os interesses do Litoral e Interior e Buenos Aires. Outra, em relação às outras províncias que compunham as Provincias Unidas del Río de la Plata ${ }^{14}$.

Em abril de 1821, a Junta de Representantes elegeu um novo governo que contava com o Ministro Bernardino Rivadavia e o General Martín Rodríguez ${ }^{15}$. Apoiado pelos grupos mais poderosos, formados por grandes comerciantes e proprietários ligados ao comércio de produtos pecuários, o ministro implementou um projeto de reformismo ilustrado, o que fez com que, aos poucos, se tornasse mais proeminente que o próprio Rodríguez ${ }^{16}$. Em uma clara tentativa de neutralizar conflitos políticos que desestabilizavam e paralisavam o governo, Rivadavia defendia o estabelecimento de cortes parlamentárias com o objetivo de institucionalizar as práticas de poder da província em um espaço dominado pela razão e pela prática deliberativa. Nesse mesmo ano, o periódico intitulado El Argos de Buenos Aires começou a ser publicado e, por toda a era rivadaviana (1821-1824), disseminou o pensamento ilustrado da elite portenha e seu discurso em torno da definição da nação rio-platense ${ }^{17}$.

A valorização da experiência hispano-americana ${ }^{18}$, sobretudo a partir de 1821 , pode ser compreendida, em certa medida e em que interessa a este estudo, justamente pelo sucesso destas reformas implementadas pelo ministro Rivadavia para solucionar a crise do período anterior. O governo de Martín Rodríguez (1821-1824) ficou conhecido na historiografia argentina por sua feliz experiência, sendo este período essencial à construção positiva da trajetória do ministro. Destacadamente construída pelas obras produzidas pela geração de liberais de 1837 e, depois, por autores tributários de suas ideias, como Bartolomé Mitre e Vicente Fidel López, que, empenhados em escrever histórias nacionais da Argentina, descreveram os anos anteriores ao governo de Rodríguez como um período de anarquia, de barbaridade política e de vazio institucional que foi solucionado pela retomada do projeto unitário, com centralização em Buenos Aires. De acordo com suas obras, o projeto liberal de Rivadavia foi capaz de solucionar os conflitos advindos da fragmentação política e territorial, de um Estado deficitário, arrasado por gastos com as guerras de independência e um aparato militar excessivo ${ }^{19}$.

Para além das medidas em si, Tulio Halperín Donghi dialoga com esta perspectiva, relativizando a originalidade da feliz experiência. Depois da vitória nas guerras

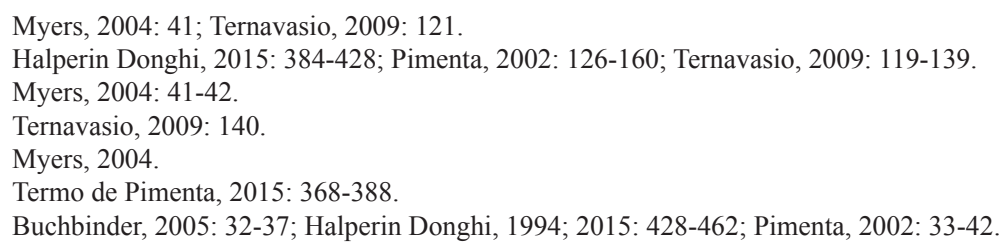


pela independência, considerando a militarização e violência como fatores essenciais à formação de uma elite dirigente, o autor afirma que o êxito e relativo consenso em torno da administração de Martín Rodríguez eram resultado de uma mudança mais ampla nos objetivos e natureza do governo, aberta por possibilidades de retorno à paz. De acordo com o autor, as linhas fundamentais de ação dos ministros de Rodríguez já eram planejadas desde o diretório de Pueyrredón (1816-1819) ${ }^{20}$. Seu plano era "desmontar a máquina de guerra" e harmonizar os interesses de distintos setores de produção e consumo, com a diferença determinante de que antes da crise de 1820 a "campanha" não tinha a proeminência política e econômica que adquiriu, levando ao consenso em torno da administração do governo de Rivadavia: "O apoio que lhe outorgaram nasce então, mais do que das realizações dessa administração, do que ela desmonta: do cuidado com que destrói o aparato militar e financeiro herdado da etapa revolucionária"21.

Entretanto, estudos mais recentes de autores negam a interpretação do vazio institucional ${ }^{22}$. Pelo contrário, quando se concentram na análise da organização político-institucional de Estados autônomos nos anos de 1820 e 1830, identificam um conjunto de instituições e relações formais que subsistiram à época das guerras de independência e se transformaram pela organização do poder, com base na unidade da cidade-província ${ }^{23}$.

Ainda neste contexto, em abril de 1821, mês da nomeação de Rivadavia em Buenos Aires, antes de embarcar do Rio de Janeiro para Portugal, D. João VI ordenou a realização do Congresso dos Povos Orientais que se reuniu nos meses de julho e agosto de 1821. Três opções foram oferecidas aos habitantes da Banda Oriental: anexarem seu território a outro governo, como Buenos Aires ou Entre Rios; constituírem um novo país ao se tornarem independentes ou anexarem-se à monarquia portuguesa. Optaram pela incorporação da Banda Oriental aos domínios portugueses, porém, no Rio de Janeiro, a representação espanhola protestou contra esta votação, bem como, os governos de Buenos Aires e Londres. Diante deste cenário, D. João VI não ratificou a anexação, porém, o general Carlos Frederico Lecor não hesitou em fazê-lo; tal desobediência custou-lhe sua destituição do posto em Montevidéu. Em reação, o general rompeu com Portugal e, intermediado por José Bonifácio de Andrada, aliou-se ao governo do Rio de Janeiro, passando, em 31 de julho, a Banda Oriental ao domínio do príncipe regente D. Pedro, sob o nome de Província Cisplatina. Depois do rompimento do Brasil com Portugal e até outubro de 1823, travou-se na região o conflito entre tropas portuguesas e as enviadas pelo Império do Brasil ${ }^{24}$.

\section{O exílio de João Soares Lisboa em Buenos Aires}

Na Corte do Rio de Janeiro, após a Aclamação de D. Pedro I como Imperador do Brasil, em outubro de 1822, a discussão centrava-se em definir o ponto de equilíbrio entre os poderes constitucionais. A preocupação era estabelecer os limites e a rela-

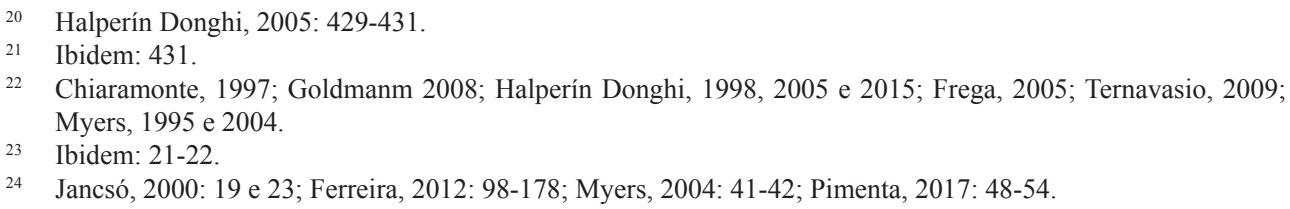


ção entre os poderes Legislativo e Executivo, formado por ministros e o rei. Neste quesito, homens em estreita proximidade com círculos de poder da Corte, tal como Frei Sampaio e José da Silva Lisboa, chamavam pejorativamente de "jacobinos" os que defendiam posicionamentos políticos mais radicais como a restrição aos poderes do rei. Outros, como João Soares Lisboa, entendiam que a defesa da atribuição ao rei do veto a leis formuladas pelos deputados era uma medida radical e própria de "corcundas" 25 . De um extremo a outro, os constitucionais se dividiam entre defender amplas atribuições monárquicas, como o veto real absoluto, e a ampla submissão da sua figura ao Legislativo, por exemplo, mediante juramento prévio do rei à constituição perante os deputados. Neste sentido, a mudança de regime absoluto para monarquia constitucional trouxe consigo o argumento forte de defesa da moderação, identificada nesse governo com a escolha por harmonizar a figura do rei com a da nação, eliminando excessos de "despotismo" e "democracia". Esta noção se consagrou como topos, segundo o qual as linguagens eram classificadas, favorecendo as que permaneciam em escalas médias de radicalização política ao resguardarem o poder do rei e do corpo Legislativo ${ }^{26}$.

O redator João Soares Lisboa parecia ter um apreço pela leitura da produção textual dos exilados que lhe serviram de exemplo substantivo e fonte de aprendizado político. Visitava obras e periódicos de autores e redatores nesta condição, inclusive, isto fazia parte da política do governo da França e de Portugal, na década de 1810. Neste sentido, Soares Lisboa acompanhava a trajetória e os jornais de João Bernardo da Rocha Loureiro; lia e transcrevia o Correio Braziliense e escolheu Civique de Gastine como referencial na definição do que o redator entendia por pacto político ${ }^{27}$. Além disto, as epígrafes no Correio do Rio de Janeiro eram transcrições dos versos de Filinto Elísio e uma homenagem a um dos mais famosos exilados portugueses, o Padre Francisco Manoel do Nascimento ${ }^{28}$.

No Rio de Janeiro, em seus últimos números do Correio do Rio de Janeiro de 1822, João Soares Lisboa destoava sensivelmente dos redatores da arena pública fluminense, especialmente quanto à definição do que chamava de governo "MonarcoDemocrático", fundado na "soberania popular" e em direitos e liberdades naturais, garantidos por lei. No limite, vislumbrava um futuro político para o Brasil que se realizaria pela república; isto lhe custou o encerramento do Correio do Rio de Janeiro, o processo na bonifácia, em que foi acusado de "conluio republicano", e o exílio do Brasil ${ }^{29}$. Em Buenos Aires viveu a efervescência da construção das repúblicas hispano-americanas recém-independentes, bem como o contexto de retorno liberal na Espanha, conhecido como Triênio Liberal (1820-23). Especialmente a imprensa fluminense do período (1823-1824) considerou seu exílio um marco de radicalização de práticas e linguagens políticas desenvolvidas nas publicações da segunda parte

25 O termo "corcunda" remete à imagem do súdito curvado e submisso ao déspota. Designava, de forma pejorativa, o defensor do ideário do Antigo Regime, contrário às ideias constitucionais inauguradas pelas Cortes de Lisboa e favorável ao absolutismo monárquico. Pereira das Neves, 2003: 132-140.

26 Ferreira, 2014.

27 Ibidem: 147-172; 2020.

28 Durante sua fuga da Inquisição Portuguesa, no final do século XVIII, refugiou-se na França. Morto em 1819, foi cultuado pelos liberais portugueses, que divulgaram a sua obra escrita sob o pseudônimo de Filinto Elísio. Mattoso, 1993: 78-79.

29 Bonifácia é o nome pelo qual ficou conhecida na historiografia a devassa aberta, em 1822, pelo ministro José Bonifácio de Andrada para investigar a organização de um "conluio republicano" que envolvia liberais. Schiavinatto, 1999; Schiavinatto - Ferreira, 2014a; Ferreira, 2017: 147-196. 
do Correio do Rio de Janeiro, escritas da prisão e que renderam a João Soares Lisboa a memória de radical e, por vezes, de republicano, ratificada por sua morte em luta na Confederação do Equador (1824).

$\mathrm{Na}$ abertura da bonifácia, no final de 1822, alguns dos réus seguiram para o exílio e se refugiaram na Europa e no extremo sul da América ${ }^{30}$. João Soares Lisboa se dirigiu à região sul do Império do Brasil, onde tinha a intenção de passar aos domínios hispano-americanos, pois lá encontraria outros negociantes que poderiam acolhê-lo, uma prática comum ${ }^{31}$. Antes de se retirar do Rio de Janeiro, em outubro de 1822, foi lhe outorgada a procuração do Alferes Francisco Teles de Sousa, negociante de Entre Rios, que lhe conferia poderes para comercializar em seu nome e justificava formalmente sua passagem do Brasil aos domínios hispano-americanos ${ }^{32}$.

Dentre os possíveis caminhos percorridos pelos exilados, esta era uma rota consagrada. Em 1822, a Secretaria de Estado dos Negócios denunciou esse itinerário ao Intendente Geral da Polícia do Paço, alertando que a cidade portenha e Montevidéu eram os destinos finais desses homens. Do Brasil embarcavam para Buenos Aires ou Montevidéu, "procurando clandestina e simuladamente meter-se a bordo de alguma embarcação [...]" nacional ou estrangeira que estivesse fora da barra, "além dos registros" de saída, partindo, por exemplo, de um "ilhote da costa". De acordo com a denúncia, era a maneira mais fácil "iludir a vigilância" aos passaportes e outros registros e finalmente "evadir-se" do Império do Brasil. No mesmo ofício, exigiase uma "vigorosa busca" aos paquetes e canoas que se destinavam a Buenos Aires e Montevidéu para descobrir e aprisionar "algum oculto indivíduo que tenha saído furtivamente", "criminosos" e "facínoras", dentre eles, especialmente, Joaquim Gonçalves Ledo ${ }^{33}$, que, juntamente com Soares Lisboa se embrenhou nesta rota, sendo que ambos se hospedaram na casa de José Rodrigues Braga, em Buenos Aires.

Em 1820, José Rodrigues Braga, comerciante português, era uma referência estratégica para o comércio e a manutenção dos domínios portugueses. Neste mesmo ano, por exemplo, logo que chegou a Montevidéu vindo da cidade portenha, foi inquerido pelo Capitão-tenente da Real Armada Portuguesa, José Pereira Pinto, acerca das operações da corveta Heroína, a antiga fragata francesa Braque. Adquirida no ano anterior pelo inglês Patrick Lynch, em 15 de janeiro de 1820, obteve licença do "Diretor Supremo das Províncias unidas ao Sul da América", José Rondeau, para navegar como "Corveta de Guerra de Buenos Aires" e autorizada a realizar a revista e aprisionamento de embarcações com bandeiras inimigas ${ }^{34}$. $\mathrm{O}$ governo português desconfiava que estivesse atuando como embarcação pirata e com o inquérito à Rodrigues Braga pretendia se informar sobre rumores de que transportava soldados portugueses desertores.

Rodrigues Braga declarou que a corveta havia saído de Buenos Aires com 201 tripulantes e 28 canhões a bordo com o objetivo de "hostilizar al Pavellon Portugués, porque con bastante publicidade se decía que ele tenía Patente de Artigas" ${ }^{35}$. Depois

$30 \quad$ Figueira de Mello, 1916.

31 Mattoso, 1993: 79.

32 Procuração do Alferes Francisco Teles de Sousa a João Soares Lisboa. Porto Alegre, 02-X-1822. $1^{\circ}$ Tabelionato de Porto Alegre. Transmissões e Notas. Códice 1815, Livro 44: 45. Agradeço a Gabriel Santos Berute por gentilmente ceder o documento.

33 Ofício da Secretaria de Estado dos Negócios ao Intendente Geral da Polícia do Paço, Paço. Lisboa, 1822. Arquivo Histórico do Itamaraty no Rio de Janeiro [Brasil] (em adiante AHI), estante 205, prateleira 02, maço 14.

34 Diário do Governo, $\mathrm{n}^{\circ}$ 106, 7-V-1822, 752-753.

35 Documento Avulso. Montevidéu, 12-IV-1820. Arquivo Histórico Ultramarino [Portugal] (em adiante AHU), rolo 02 , doc. 126 . 
de colher esse depoimento, o Vice-almirante Rodrigo José Ferreira Lobo, Chefe de Esquadra e Comandante das Forças Navais do Rio da Prata, comunicou a questão ao Conde dos Arcos em 13 de abril de 1820 e solicitou que a fragata portuguesa União fizesse uma revista da Heroína, recuperasse os mais de 60 soldados portugueses desertores que ela transportava, e verificasse se ela teria "roubado alguma embarcação" ou atuado com "outra qualquer Patente que não seja a de Buenos Ayres". Finalizou, solicitando que embarcações fossem posicionadas "defronte" a Buenos Aires e que a esquadra fosse guarnecida com marinheiros e tropas em Montevidéu ${ }^{36}$.

De 1816 a 1820 Artigas disputou o domínio da região. As informações prestadas por José Rodrigues Braga demonstravam sua fidelidade ao Império Português diante da importância da vigilância de Buenos Aires, que ocupava um lugar estratégico nos eventos do que ficou conhecido como Campanhas da Cisplatina. Esta posição se manteve após a independência do Brasil com a continuada tensão entre as forças portuguesas estacionadas em Montevidéu e as tropas lideradas pelo Barão de Laguna em defesa dos interesses do Império do Brasil. Ademais, a natureza das preocupações do governo português em relação às ações da corveta e a associação desta com a "Patente de Artigas", no depoimento de José Rodrigues Braga, fortalecem a imagem de Artigas como líder imoral e violento, que utilizava de ações arbitrárias e ilegais, tal como a pirataria ou cooptação de soldados. Como se verá, apesar de ter se retirado da região para o Paraguai, em 1822, este imaginário perdurou ${ }^{37}$.

Em setembro de 1821, José Rodrigues Braga se envolveu em uma polêmica noticiada pelo El Argos de Buenos Aires. Durante a comemoração do aniversário de juramento da Constituição de Portugal, no Coliseu de Montevidéu, Rodrigues Braga, acompanhado do Cônsul dos Estados Unidos, Miller, foi encurralado por soldados mascarados liderados pelo Coronel português Claudino. Foi atacado com insultos de "maroto", atingido por duas pauladas no rosto, e ameaçado de morte, caso não saísse de Montevidéu dentro de três dias. No dia seguinte, apesar de o Barão de Laguna garantir sua segurança, o negociante se retirou para Buenos Aires. A polêmica se alongou em edições posteriores do $E l$ Argos, com a publicação da versão do próprio Braga e de correspondentes ${ }^{38}$. A polêmica explicita o reconhecimento e o trânsito de Braga na região, sua associação com o Cônsul dos Estados Unidos, sua habilidade e preocupação com o conceito recorrente que se fazia de Artigas na região.

El Argos publicou sobre Braga que ele era um "ciudadano portugués, cuya finura y educación es bien conocida em esta ciudad [...]", em oposição ao Coronel Claudino que era apelidado de "Touro", com direito a uma gravura do animal e o título "Hai Vai Touro" 39 . Em cartas dos correspondentes e de Rodrigues Braga estabelece-se a

36 Documento Avulso. Montevidéu, 13-IV-1820. AHU, CU-065, rolo 02, doc. 128.

37 Os conflitos na região foram chamados genericamente Campanhas da Cisplatina. Englobam diversas disputas [para evitar repetir 'conflitos' duas vezes] que se estenderam de 1811 a 1828, com antagonismos políticos entre orientais, portenhos e espanhóis, decorrentes da Revolução de 1810 e dos interesses de Portugal e do governo do Brasil na região. Com o objetivo de impedir a anexação da Banda Oriental pelas Províncias Unidas do Rio da Prata, a primeira Campanha iniciou com a invasão da região por tropas portuguesas, em 1816. Os conflitos persistiram entre portenhos e orientais; estavam associados à tomada de Montevidéu por Artigas e se desdobraram na segunda Campanha. Entretanto, a principal motivação para conquistar a Banda Oriental era a derrota do projeto revolucionário artiguista. Kühn, 2002: 78-79. Em 1820, quando a Banda Oriental foi anexada ao Reino do Brasil, Artigas se exilou no Paraguai e nunca retornou Wiederspahn, 1956.

38 El Argos de Buenos Aires, no 25-IX-1821 e 29-IX-1681, 166-167; nº 26, 06-X-1821, 174-175; nº 27, 13-X-1821, 181-182.

39 El Argos de Buenos Aires, n 26, 06-X-1821; n 27, 13-X-1821, 181-182. 
contraposição entre sua imagem de autointitulado "liberal por carácter y por principio", que gozava da "mejor opinión em Buenos-Aires", e de "un ciudadano formado entre la grita y el tumulto, como el coronel asesino", "à quien se le reputa como el primer violador de todas las libertades", "déspota" que se utiliza da violência e arbitrariedade da "espada de sus soldados", é "anticonstitucional", "enemigo de todo americano" e, por isto, associado a um touro bravio, irracional ${ }^{40}$.

Neste ponto, o Coronel era comparado a quem de mais criminoso havia: Artigas. Com o agravante de que Claudino era uma autoridade do governo e não um "errante". $\mathrm{Na}$ "cadena de los crímenes" de Artigas, não havia nenhum tão "degradante" como o executado pelo Coronel: "Artigas sin ley, sin dependencia, errante, viviendo entre hordas de salvajes, mandaba fusilar y consentía todos los sacrificios. Mas el coronel Claudino jurando las leyes, que por primera vez à establecido su país, con un jefe à la cabeza, en una sociedad ordenada ejecuta iguales sacrificios por sí mismo"41.

A comparação publicada em El Argos, em 1821, expôs a imagem pejorativa de Artigas na região que, por fim, incorporava os adjetivos atribuídos ao Coronel português. Isto fortalecia, dava veracidade e urgência às missivas do Cônsul Câmara contra Soares Lisboa e seus associados. Como demonstram estas publicações, a aliança com Artigas não era real, mas servia à argumentação do Cônsul do Brasil para denegrir e criar suspeitas sobre Soares Lisboa, Rodrigues Braga e Gonçalves Ledo.

As desconfianças que vinham sendo alimentadas contra a Heroína desde 1820 somente foram averiguadas em 1822, fomentando e reavivando o imaginário negativo de Artigas, já que este a utilizava ${ }^{42}$. Um processo aberto pela Marinha portuguesa, a partir de confissões e testemunhas, comprovou ações piratas violentas perpetradas contra navios de Portugal, Espanha, Inglaterra e dos Estados Unidos e o envio de cargas roubadas para Buenos Aires ${ }^{43}$. A condenação da Heroína convergia com o imaginário em torno da figura de Artigas como líder violento e envolvido em tramas ilegais, bem como ratificava a declaração de Rodrigues Braga a respeito da associação de Artigas com essa embarcação pirata. Também conferia veracidade às leituras da geopolítica da região que, como se verá, foram disseminadas através das missivas do Cônsul do Brasil em Buenos Aires, o conselheiro Antônio Manoel Correia da Câmara ${ }^{44}$.

Neste mesmo ano, Rodrigues Braga liderou a representação, com a qual os negociantes portugueses em Buenos Aires declaravam subordinação ao Príncipe D. Pedro $^{45}$. Ele mantinha, assim, sua importância, aderindo ao processo de independência do Brasil e construção do Império do Brasil. Foi com esse intuito que ele hospedou

40 El Argos de Buenos Aires, n 26, 06-X-1821, 176; n 25, 29-IX-1821, 167.

$41 \quad$ El Argos de Buenos Aires, $\mathrm{n}^{\circ}$ 25, 29-IX-1821, 167.

42 Astro da Lusitânia, ${ }^{\circ}$ 109, 26VII-1822; Gazeta Universal, nº 70, 29-III-1822, 283; $\mathrm{n}^{\circ}$ 210, 23-IX-1822, 847; ${ }^{\circ}$ 230, 17-X-1822, 929; n 21, 28-I- 1823, 90; nº 31, 8-II-1823, 127-128; Diário do Governo, no 106, 7-V-1822, $752-754$.

43 Diário do Governo, no 106, 7-V-1822, 752-754.

44 Nascido no Rio Pardo, foi enviado, ainda criança, por seu pai para estudar em Portugal. Era filho de Patrício José Correia da Câmara, primeiro Visconde de Pelotas. Formou-se no Colégio dos Nobres, em Lisboa. Em 1807, durante a primeira invasão do reino lusitano por tropas francesas chefiadas pelo General Junot, foi forçado a alistar-se em seu exército. Depois de libertado, finalizou seus estudos e viajou pela Europa até a Índia, onde serviu como ajudante de ordens do governador da colônia. No ano de 1816, após a proclamação das Províncias Unidas do Rio da Prata, a Coroa portuguesa o nomeou agente comercial e político na região. Guimarães, 1938; Alegre, 1981: 90-91; Camargo, 1877: 505-506; Landgraf Piccolo, 2005: 591.

45 Correspondência do cônsul do Brasil em Buenos Aires, Antônio Manuel Correia da Câmara (1822-1823). Buenos Aires, 05-V-1823. AHI, estante 205, prateleira 02, maço 14. 
os exilados e o Cônsul do Brasil em Buenos Aires. Em maio de 1822, após a morte de João Manuel de Figueiredo, o Ministro José Bonifácio de Andrada nomeou Cônsul do Brasil em Buenos Aires, Antônio Manoel Correia da Câmara. Uma das suas principais incumbências era negociar territórios e acordos estratégicos, utilizandose das suas alianças com as tropas aliadas, chefiadas pelo Barão de Laguna ${ }^{46}$ e com a Junta de Representantes de Buenos Aires. Os primeiros anos da década de 1820 em Buenos Aires foram marcados pela efetivação do plano de reconstrução política e econômica de Bernardino Rivadavia. Seu nome era recorrente nos relatos sobre a experiência hispano-americana de exílio de Soares Lisboa. Além de compartilharem de um ideário reformista, sua associação envolvia interesses comerciais. Afinal, Soares Lisboa tinha experiência no trato mercantil com militares, negócios pecuários nas fronteiras do Rio Grande e inserção no comércio de grosso trato do Rio de Janeiro ${ }^{47}$.

O plano estratégico de José Bonifácio de Andrada era conciliar os interesses na formação do que ele chamava de "Confederação ou Tratado ofensivo e defensivo" entre Buenos Aires, Paraguai, Entre Rios, Montevidéu e o Brasil. A estratégia traçada tinha duas frentes de negociação. Uma era com o governo do Paraguai, cujo objetivo era criar uma nova aliança para consolidar, junto a Montevidéu, um cordão estratégico que daria aos "brasileiros" o controle da entrada e saída de víveres, pessoas e letras de câmbio para as demais regiões hispano-americanas coloniais e as independentes e para as futuras nações autônomas. A expectativa era garantir a aliança com o Paraguai e o domínio de Entre Rios pelo Brasil. A outra frente era a negociação direta com o governo de Buenos Aires que seria pressionado pelos sucessos das alianças do Brasil com Paraguai, Entre Rios e Montevidéu ${ }^{48}$. Além disso, outra recomendação era que Câmara lhe enviasse por correspondência informações sobre o avanço dessas negociações.

Em suas missivas, o Cônsul enviava jornais - com destaque para El Argos de Buenos Aires - acordos, panfletos, decretos e outros impressos que documentavam a proliferação e circulação de publicações, reimpressões de periódicos e documentos oficiais no sul da América. Preocupado em promover sua imagem como defensor do Imperador, do governo do Brasil e da ordem constitucional, ou por ter sido incapaz de enxergar nuances, Correia da Câmara equiparava modos de entender a monarquia constitucional ao ser pró-português, "republicano", "jacobino", "anarquista" e contra a "Causa do Brasil". Entretanto, ao se analisar mais detidamente a trajetória dos exilados, sobretudo a de João Soares Lisboa, e buscar extrapolar as categorias binárias criadas nos julgamentos de seus conterrâneos, apreende-se que seus posicionamentos e concepções ao respeito do governo por uma monarquia constitucional não se restringiam a ou constituíam uma defesa de um tipo específico de regime político,

46 O general português Carlos Frederico Lecor, mais tarde Barão de Laguna, vitorioso nos combates às tropas lideradas por Artigas contra a ocupação da Banda Oriental, foi responsável pelas negociações com o Cabildo de Montevidéu e se consagrou ao firmar o pacto que estabeleceu a ocupação pacífica da Província Cisplatina pelos portugueses a partir de janeiro de 1817. Sobre isto, Câmara afirmou obter sido o "meio único de garantir a paz", conservar a política portuguesa e acabar com a "seita perversa" de Artigas. (Pimenta, 2017: 48-54; Correspondência Antônio Manuel Correia da Câmara (1822-1823). Buenos Aires, 12-XI-1822. AHI, estante 205, prateleira 02, maço 14.)

47 Ferreira, 2017: 235-261.

48 Instruções para Sr. Antonio Manoel Correa da Câmara na Comissão em que parte desta Corte de Agente junto ao Governo de Buenos Aires e mais Portos adjacentes. Rio de Janeiro, 31-V-1822. AHI, estante 205, prateleira 02 , maço 14 . 
monárquico ou republicano. Definiam-se, antes, por outros elementos; por exemplo, pelas formas de participação e representação política, divisão e atribuição de poderes no governo, definição de soberania e pacto, recriando-a a partir da polissemia destes conceitos políticos ${ }^{49}$.

Em 14 de novembro de 1822, chegava o "Anti-Brasileiro", "Carbonário Autor do Correio" João Soares Lisboa e, mais tarde, em 2 de dezembro, Joaquim Gonçalves Ledo, que, para o Cônsul, fora trazido graças à "amizade que tem com Lisboa". O Cônsul Correia da Câmara reclamava que a casa de José Rodrigues Braga era um centro de encontro de brasileiros e portugueses que, durante ceias ou "conversas noturnas", debatiam os últimos acontecimentos políticos, opinavam sobre formas de governo, discutiam a geopolítica da América e definiam estratégias comerciais ${ }^{50}$. Estas descrições revelam que, nestas reuniões, os exilados fortaleciam vínculos com seus correspondentes no Brasil, construíam uma experiência comum por meio da informação, assentada em uma identidade com base em elementos morais e políticos. O Cônsul entendia tais conversas, encontros e troca de correspondência como parte da organização de uma trama contra D. Pedro I e a "Causa do Brasil" para a implementação de uma república ${ }^{51}$.

O Cônsul utilizava o termo "republicano" para designar Soares Lisboa, Gonçalves Ledo e Rodrigues Braga como "jacobinos", adeptos da maçonaria e membros do que chamava de "Club Militar de Montevidéu". Este estaria sob influência de Artigas, recuperando seu imaginário na região. Justificava-se, primeiro, com a devassa, pela qual Gonçalves Ledo e Soares Lisboa estavam sendo processados no Rio de Janeiro. Em segundo lugar, com as amizades que eles nutriam no extremo sul do Império do Brasil e na região de Buenos Aires e Montevidéu. E, por fim, com as opiniões verbalizadas nos encontros na casa de José Rodrigues Braga ou expressas em cartas por eles recebidas do Brasil, que eram lidas em voz alta em ditas reuniões ${ }^{52}$.

De acordo com Correia da Câmara, havia, em Montevidéu, um "Club" aliado às Cortes portuguesas e espanholas que tinham a pretensão de retomar seus domínios na América. Os membros desta "seita" ou "cabala" estariam sob a influência do "imoral" "Tigre Artigas", um "Monstro" dotado de "Jacobinismo", e um "perfeito Sans-Culotte", que lideraria a "facção europeia em Buenos Aires" e disseminaria impressões negativas sobre o Império do Brasil para "levar a Anarquia e o Extermínio ao centro das novas Povoações e estabelecimentos". Com um "febricitante desejo das inovações constitucionais", contariam com "numerosos Agentes dos clubs carbonários de Portugal, Espanha, Itália, França e Inglaterra derramados por todo o

49 Sobre a ideia de "recriação" de termos políticos: Pimenta, 2017: 7-56. Cf. Fernández Sebastián, 2009 e 2014.

50 Correspondência do cônsul do Brasil em Buenos Aires, Antônio Manuel Correia da Câmara (1822-1823). Buenos Aires, 01-XI-1822 e 26-XI-1822. AHI, estante 205, prateleira 02, maço 14.

51 Correspondência do cônsul do Brasil em Buenos Aires, Antônio Manuel Correia da Câmara (1822-1823). Buenos Aires, 02-XII-1822 e 14-XII-1822. AHI, estante 205, prateleira 02, maço 14.

52 Correspondência do cônsul do Brasil em Buenos Aires, Antônio Manuel Correia da Câmara (1822-1823). Buenos Aires, 12-XI-1822 e 14-XI-1822. AHI, estante 205, prateleira 02, maço 14. Enviava a seguinte "relação nominal dos súditos do Império do Brasil residentes em Buenos Aires que ali se declararam inimigos do atual sistema do Governo Imperial": Joaquim Gonçalves Ledo, João Soares Lisboa, José Rodrigues Braga, Manuel C. Francisco Canedo, José Rodrigues Monteiro, Miguel Lopes Chavez, José Fernandes Pinto, Manuel José da Silva, Antônio Bernardes Machado, José Fortes Gonçalves, José Francisco de Amorim, Manuel de Azevedo Ramos, "o autor do Compilador do Rio de Janeiro", Manuel José, Manuel Dias da S. Guimarães, Maquez, "(caixeiro da Casa Britain)", José da S. Ramos, Ignácio Piloto, Bernardo José da Beça Brandão (Correspondência do cônsul do Brasil em Buenos Aires, Antônio Manuel Correia da Câmara (1822-1823). Rio de Janeiro, 07-V-1823. AHI, estante 205, prateleira 02, maço 14). 
Brasil, como pelas províncias do Prata" ${ }^{53}$. Assim, o Cônsul partia da imagem disseminada de Artigas, do contexto de conflitos entre tropas do Brasil e de Portugal em Montevidéu e das redes políticas e comerciais que englobavam Montevidéu, Buenos Aires e o Rio Grande para confeir veracidade às suas elaborações sobre uma trama de reconquista europeia e um plano republicano dos exilados.

Ao utilizar esta representação, o Cônsul se alinhava com a imagem disseminada por determinado grupo de poder, retomava e dava repercussão à construção de "desconfiança" ao estrangeiro presente na política do governo da Corte, sobretudo, na década de 1810 e em relação aos hispano-americanos no Rio da Prata, por ser uma região fronteiriça e de intercâmbio inevitáve ${ }^{54}$. Estrangeiros eram vistos como perigo iminente, produtores de ideias contestadoras, revolucionárias e subversivas. Em 1822, Correia da Câmara associava a isto o imaginário que se perpetuava em Montevidéu e Buenos Aires em torno de Artigas como sendo déspota, violento e imoral, embora ele tenha se retirado da região em 1820, rumando para o Paraguai ${ }^{55}$. Apesar de incoerentes, suas afirmações se fortaleciam mediante o cenário europeu de combate a liberais pelas tropas da Santa Aliança, o processo, ainda em curso, de reconhecimento da Independência do Brasil por Portugal e os desdobramentos de possíveis alianças com Estados Unidos, as repúblicas hispano-americanas e com a Inglaterra $^{56}$.

Diante deste cenário de grandes conflitos e complexidade, Correia da Câmara escrevia que, a despeito das dificuldades, as negociações com Rivadavia caminhavam para a conciliação com o apoio do Barão de Laguna ${ }^{57}$. Entretanto, o Cônsul responsabilizava as armações e influência de Gonçalves Ledo, Soares Lisboa e Rodrigues Braga pela mudança na posição de Rivadavia em relação à manutenção do domínio da Banda Oriental pelo Império do Brasil ${ }^{58}$. Descrevia uma série de armações organizadas por eles que teriam usado de "meios mais vis", "monstruosos e vergonhosos", como a violação e adulteração de cartas trocadas entre ele e José Bonifácio de Andrada, o Barão de Laguna e o próprio Ministro Rivadavia, e um motim com a participação de pardos da Banda Oriental ${ }^{59}$. O Cônsul relatava ter recebido notícias de finalidades ainda mais "perigosas", a venda, em Buenos Aires, de "várias armas de Infantaria por um Agente de Entre Rios a troco de Couros", que mais tarde seriam utilizadas em Montevidéu contra as tropas do Brasil.

53 Correspondência do cônsul do Brasil em Buenos Aires, Antônio Manuel Correia da Câmara (1822-1823). Buenos Aires, 12-XI-1822. AHI, estante 205, prateleira 02, maço 14.

54 Schultz, 2008: 170-171.

55 Wiederspahn, 1956.

56 Alexandre, 1993.

57 Instruções para Sr. Antonio Manoel Correa da Câmara na Comissão em que parte desta Corte de Agente junto ao Governo de Buenos Aires e mais Portos adjacentes. Rio de Janeiro, 31-V-1822. AHI, estante 205, prateleira 02 , maço 14 .

58 Correspondência do cônsul do Brasil em Buenos Aires, Antônio Manuel Correia da Câmara (1822-1823). Buenos Aires, 14-XII-1822. AHI, estante 205, prateleira 02, maço 14.

59 Correspondência do cônsul do Brasil em Buenos Aires, Antônio Manuel Correia da Câmara (1822-1823). Buenos Aires, 08-XI-1822; 02-XII-1822 e 14-XII-1822; Rio de Janeiro, 16-IV-1823. AHI, estante 205, prateleira 02, maço 14. Correia da Câmara alertava Bonifácio de Andrada sobre o envolvimento de Joaquim Gonçalves Ledo também com militares de origem negra no sul da América, no caso, com o Tenente da Artilharia Cívica Thomas Gomes. Ele teria passado de Buenos Aires à Colônia com o intuito de sublevar negros da Banda Oriental, pra o Cônsul, fato preocupante "mesmo com os poucos negros que pode ter a Província de Montevidéu" (Correspondência do cônsul do Brasil em Buenos Aires, Antônio Manuel Correia da Câmara (1822-1823). Buenos Aires, 11-I-1822. AHI, estante 205, prateleira 02, maço 14). 
As informações de Câmara, sobretudo a respeito do republicanismo de Soares Lisboa e seus aliados devem ser relativizadas. Entretanto, sua rede e atividade comercial na região, somadas à proeminência de José Rodrigues Braga como negociante e entre autoridades de Montevidéu, Buenos Aires e dos Estados Unidos, de certa forma validavam as acusações do Cônsul do Brasil. Em relação ao trato mercantil, pode-se citar um dos possíveis aliados de Soares Lisboa, Manuel Francisco Canedo. Listado como inimigo "do atual sistema do Governo Imperial" do Brasil pelo Cônsul, possivelmente participava destas negociações de armas e couros entre Montevidéu e Buenos Aires, mencionadas pelo Cônsul Câmara. Em colaboração com Soares Lisboa, autorizado como "Agente de Entre Rios" por procuração recebida antes do seu exílio ${ }^{60}$, Canedo era responsável por receber gêneros vindos de Montevidéu, em Buenos Aires, e, de lá, despachar produtos para o Rio de Janeiro ${ }^{61}$. Em suas missivas, essas negociações eram tidas como indício de uma trama contra os interesses do Império do Brasil e convergiam o imaginário destes liberais com o de $\operatorname{Artigas}^{62}$.

\section{O Correio do Rio de Janeiro no Cone Sul da América}

Na descrição feita na correspondência de Correia da Câmara, os debates políticos dos exilados extrapolavam os espaços privados e se disseminavam no público. Eles pregavam "pelas ruas e armazéns desta Cidade [de Buenos Aires] as maiores imposturas contra o Brasil e o seu governo", imprimiam e espalhavam libelos contra o Cônsul e D. Pedro I. Um dos panfletos que ficou mais "famoso" foi o que iniciava com "D. Ramon, primeiro sem segundo"63, dizeres que o Cônsul associou aos do Correio do Rio de Janeiro, de outubro de 1822: "Eis o Pedro $1^{\circ}$ sem $2^{\circ}$ !!" para conferir veracidade às suas denúncias contra os exilados ${ }^{64}$. Nesta oportunidade, esta publicação foi decisiva para a ordem de encerramento do jornal e de exílio do redator. Tal exclamação tornou-se uma espécie de lema e foi rapidamente relacionada à defesa de uma república no Brasil por Soares Lisboa. Antes disto, em $1^{\circ}$ de novembro de 1822, juntamente com muitos exemplares de jornais lidos em Buenos Aires e Montevidéu, tais como o Sentinela da Bahia, o Semanário Cívico, gazetas do Chile como o Mercúrio, notícias de Lima, o Cônsul enviou a Bonifácio de Andrada o $\mathrm{n}^{\circ} 03$ do Correio Extraordinário do Rio de Janeiro, datado de 21 de setembro de 1822. Segundo suas

60 Procuração do Alferes Francisco Teles de Sousa a João Soares Lisboa. Porto Alegre, 02-X-1822. $1^{\circ}$ Tabelionato de Porto Alegre. Transmissões e Notas. Códice 1815, Livro 44: 45.

${ }_{61}$ Em 14 de janeiro de 1822, recebeu em Buenos Aires a embarcação portuguesa "Sociedad Feliz, precedente de Montevideo", carregada com "yerba, tabaco y otros renglones" (El Argos de Buenos Aires, no 19, 23-I-1822, 77). Em 25 de janeiro de 1822, despachou pelo bergantim português Aguila del Duero "7950 pesos de plata sellada, 65000 aspas, 1250 quintales carne salada, 349 arrobas sebo, y 4 arrobas velas" (El Argos de Buenos Aires, $\mathrm{n}^{\circ}$ 4, 30-I-1822, 13). Em 18 de outubro de 1822, despachou o bergantim português Minerva para "puertos del Brasil" (El Argos de Buenos Aires, n 80, 23-X-1822. 325). Em 7 de dezembro de 1822, despachou para o Rio de Janeiro o bergantim português Aguila del Duero com "460 quintales carne salada, 45 docenas cueros de carneiro, 55 quintales de cacao, 37 piezas de razo y 20 cajones de cigarros” (El Argos de Buenos Aires, $\mathrm{n}^{\circ}$ 94, 11-XII-1822, 381).

62 Correspondência do cônsul do Brasil em Buenos Aires, Antônio Manuel Correia da Câmara (1822-1823). Buenos Aires, 27-XII-1822 e 03-I-1823. AHI, estante 205, prateleira 02, maço 14.

63 Correspondência do cônsul do Brasil em Buenos Aires, Antônio Manuel Correia da Câmara (1822-1823). Buenos Aires, 14-XII-1822. AHI, estante 205, prateleira 02, maço 14; Schiavinatto - Ferreira, 2014b: 335.

64 Correio do Rio de Janeiro, $\mathrm{n}^{\circ}$ 157, 19-X-1822, 697. 
informações, a edição fora reimpressa em Montevidéu, acrescentando "notas que foi obrigado a pôr-lhe o Editor de Montevidéu" a pedido do "Club Militar", que mandou "reimprimir" 65 .

Esta edição do Correio do Rio de Janeiro fora impressa especialmente por Soares Lisboa, no Rio de Janeiro, para tratar da Aclamação de D. Pedro como Imperador do Brasil, em 12 de outubro. O redator vibrava com o acontecimento, aprovava o "Imortal Pedro" na qualidade de "Primeiro Cidadão" dos "Portugueses do Brasil" e ponderava que seriam necessárias "paciência" e "razão" para aguardar a reunião do corpo municipal no dia 12, a fim de não precipitar um evento fora da legalidade, que poderia causar "tumulto". Além do edital de proclamação, Soares Lisboa também reproduziu, no Correio, o decreto de 18 de setembro de 1822, que definia o modo de proceder em relação à adesão ao Império do Brasil, especialmente de portugueses nascidos fora do seu território, o que era o caso do próprio Soares Lisboa, natural do Porto.

O decreto anistiava a todos por "passadas opiniões políticas até a data deste Meu real Decreto, excluídos todavia dela [anistia] aqueles que já se acharem presos, e em processo", ficando "Todo o Português Europeu, ou Brasileiro que abraçar o atual Sistema do Brasil, e estiver pronto para defendê-lo" identificado por uma "flor verde dentro do ângulo d'ouro no braço esquerdo com a legenda 'Independência ou morte"'. Aquele que não aderisse à "Causa" deveria sair da cidade de sua residência dentro de trinta dias e do Brasil em um prazo de quatro meses para as cidades centrais e de dois meses para as cidades marítimas, a contar da data do decreto. Caso contrário, se "[atacasse] o dito sistema [do Brasil], e a Sagrada Causa do Brasil, ou de palavra, ou por escrito" seria "processado sumariamente, e punido com todo o rigor das Leis" aplicáveis aos "réus de Lesa-Nação e perturbadores da tranquilidade pública"66.

Em números anteriores do Correio do Rio de Janeiro, Soares Lisboa criticara manifestações de nativismo de portugueses de ambos os reinos e defendera a exclusividade do critério de adesão em detrimento da naturalidade para a definição de cidadania do Império do Brasil ${ }^{67}$. Acreditava que a busca da liberdade era o que unificava os portugueses do novo império, inclusive, incluía D. Pedro I, pois a defesa da lei era o critério, pelo qual os cidadãos deveriam ser medidos e não o local de nascimento. Neste sentido, pode-se dizer que o Correio Extraordinário do Rio de Janeiro $\mathrm{n}^{\mathrm{o}} 03$ trazia informações estratégicas ao público em Montevidéu. Isto explicaria sua reimpressão, que evidencia o estratagema político de Soares Lisboa e a sua aliança com tipógrafos em Montevidéu. Possivelmente, as publicações destes impressores constituíram as novas leituras de Soares Lisboa no exílio e transformaram suas edições do Correio do Rio de Janeiro de 1823, quando retornou ao Rio de Janeiro.

A partir do Correio Extraordinário do Rio de Janeiro ${ }^{\circ}$ 03, João Soares Lisboa dialogava com uma série de homens que até então não haviam aderido totalmente à "Causa": os nascidos em Portugal que temiam o futuro de seus bens, propriedades e cargos e todos aqueles que receavam a guerra entre portugueses e brasileiros. A reedição da edição extraordinária do Correio também era uma tentativa de colocar

65 Correspondência do cônsul do Brasil em Buenos Aires, Antônio Manuel Correia da Câmara (1822-1823). Buenos Aires, 01-XI-1822. AHI, estante 205, prateleira 02, maço 14. Na documentação há poucos anexos preservados, por exemplo, não há a reimpressão do Correio do Rio de Janeiro.

66 Correio do Rio de Janeiro, $\mathrm{n}^{\mathrm{o}}$ 3, 21-IX-1822.

67 Correio do Rio de Janeiro, $n^{\circ} 49,07-V I-1822 ; n^{\circ} 85,26-I X-1822 ; n^{\circ} 98,10-V I I I-1822 ; n^{\circ} 117,03-I X-1822 ; n^{\circ}$ $141,01-\mathrm{X}-1822$. 
fim às denúncias e tensões de perturbação e traição, comuns até então, especialmente em Montevidéu. Lá, o campo de possibilidades era muito amplo, havia vários caminhos políticos além da adesão ao Império do Brasil, tais como manter-se unido ao governo de Portugal, aliar-se ao governo espanhol ou mesmo formar, com Buenos Aires e outros territórios hispano-americanos recém-independentes, uma federação ou confederação americana.

Com esse decreto, perdoavam-se os crimes de perturbação da ordem, de modo a conter antagonismos. Ao mesmo tempo, sua publicação tinha muitos interlocutores em Montevidéu e, junto aos conselhos de João Soares Lisboa, mostrava aos militares que a situação na Corte do Rio de Janeiro estava controlada e tinha a anuência das tropas. Neste sentido, produziria o mesmo efeito nos militares de Montevidéu. Entretanto, dependendo do conteúdo das anotações publicadas e mencionadas por Câmara, significaria um esforço dos homens da divisão dos voluntários reais, liderados por D. Álvaro da Costa de Souza de Macedo, em desmentir a versão de Soares Lisboa sobre a adesão das tropas à D. Pedro I. Esta possibilidade não era aventada pelo Cônsul, pois ele entendia haver uma aliança entre os membros do "Club Militar" de Montevidéu e o redator do Correio do Rio de Janeiro.

De acordo com Câmara, a publicação dos libelos e a disseminação dos debates nas ruas teriam criado uma opinião favorável em relação aos exilados, o que o preocupava e impedia a efetivação do seu plano de pedir ao ministro Rivadavia a expulsão dos "dois Carbonários" de Buenos Aires. Em sua última conferência com ele, anunciou sua transferência para o Rio de Janeiro, deixando Francisco da Costa Pereira para substituí-lo.

\section{Republicano e liberal?}

Neste conflito por territórios, a participação de João Soares Lisboa no exílio abrangia também negociações de víveres, armas, letras de câmbio e circulação de pessoas e impressos entre Montevidéu e Buenos Aires, o que foi um fator fundamental para sua condenação por "conluio republicano", em julho de $1823^{68}$. Entretanto, a associação entre sua atuação junto aos hispano-americanos no comércio e imprensa e sua pecha de republicano mostra a multiplicidade de significados de conceitos políticos fundamentais que foram apropriados por João Soares Lisboa e disseminados nas regiões do antigo Vice-Reinado do Rio da Prata, e assim o vinculam ao imaginário em torno das figuras como Bernardino Rivadavia ou José Gervásio Artigas. De forma semelhante ao papel do ministro José Bonifácio de Andrade na trajetória de Soares Lisboa, Artigas exerceu papel importante na construção de uma memória histórica sobre sua experiência hispano-americana. Precursor do federalismo na região do Prata, emergiu como produto das guerras de independência e de suas organizações políticas informais, as montoneras ${ }^{69}$. Neste sentido, Ana Frega revisa a memória histórica sobre Artigas, escapando à armadilha de considerá-lo herói nacional, fundador da nacionalidade uruguaia, bandoleiro e caudilho anarquista. A autora o analisa como um caudilho ilustrado que possuía um projeto de governo epretendia educar a consciência política dos cidadãos e magistrados, tornando-os virtuosos, organizados

\footnotetext{
Ferreira, 2017: 233-253.

69 Goldman - Salvatore, 2005: 16; Lynch, 1993: 60-64; Pimenta, 2002: 115-116.
} 
em uma "soberanía particular de los pueblos" em oposição ao centralismo de Buenos Aires $^{70}$.

Tal como analisa Miriam Dolhnikoff, a reivindicação por e a definição de um arranjo de Estado nacional com autonomia das unidades particulares, como províncias, não significava necessariamente a defesa de um governo republicano; comportava também a monarquia dentre a diversidade de regimes inserida na definição de governo representativo ${ }^{71}$. Neste caso, sendo possível conciliar o conceito de soberania particular com o de regime monárquico. Também vislumbra a apropriação dos agentes sociais de diferentes concepções de nação que mantinham um arranjo com a figura de um rei ${ }^{72}$. Por sua vez, a apropriação do termo republicano, em sua polissemia, extrapolava a definição de um regime estrito senso, e incluía noções tão amplas para autores como Pocock e Skinner que, segundo Javier Fernández Sebastián, permitiriam repensar uma oposição liberalismo e republicanismo ${ }^{73}$. Desta maneira, João Soares Lisboa valorizava a escolha autônoma e sentimental do cidadão e não o seu local de nascimento, diferenciando-se do que, em geral, apresentavam os discursos que defendiam a autonomia provincial pelo termo pátria ou patriotismo, canalizando esta identidade e ampliando a ideia de "pátria", que denominou "Governo Monárquico Constitucional"'74.

Apesar de autores como Marcello Basile e Silvia Carla Fonseca não tratarem particularmente das publicações do Correio do Rio de Janeiro, suas análises oferecem definições que contribuem para a indagação quanto à radicalidade da trajetória pública de João Soares Lisboa e, sobretudo, para a reflexão sobre sua qualificação republicana. O primeiro autor emprega o que chama de experiência republicana para analisar os projetos de Brasil e a ação política na Corte regencial. Também discute a politização, no Período Regencial, de práticas informais de cidadania, com a participação de atores até então marginalizados da política. Abria-se a esfera cívica às camadas médias urbanas e aos estratos de baixa condição social, por exemplo, em festividades e protestos ${ }^{75}$. Sua leitura expande as possibilidades de análise da questão das ideias republicanas como práticas políticas cidadãs, consideradas experiências que não dependiam necessariamente do regime de governo institucionalizado. De acordo com esta noção de ideias republicanas, o projeto de Brasil, as formulações e convicções de João Soares Lisboa sobre o exercício de um espaço cívico na monarquia, alimentadas por sua experiência hispano-americana no exílio, antecipavam a defesa desta experiência republicana já nos anos de 1822 e 1824 .

Por sua vez, diante do caráter polissêmico do conceito de república, Silvia Carla Fonseca historiciza a linguagem republicana e identifica elementos fundamentais deste conceito, que envolvia a noção de império da lei, com a primazia do bem comum, e um regime de governo eletivo e temporário. De acordo com a autora, na primeira metade do século XIX, no Brasil, os escritos políticos das províncias do Rio de Janeiro e Pernambuco apresentavam uma espécie de herança dos discursos republicanos, que se mostrava na defesa da precedência da coisa pública e do bem comum, independente de uma forma de governo específica. Tal postura convergia

\footnotetext{
Frega, 2005.

Dolhnikoff, 2005.

Berbel, 1999.

Fernández Sebastián, 2009: 731.

Ferreira, 2017: 147-196 e 295-321.

Neri de Campos Basile, 2004: 15.
} 
para a tendência liberal de escolher a monarquia constitucional e, como afirma Xavier Guerra, de defini-la com elementos tributários da tradição do humanismo cívico. Em um momento de formação de uma esfera pública, relacionada com a expansão da imprensa e de sociabilidades, esta herança e tradição se desenvolveram em mecanismos informais de participação política que foram amplamente disseminados no Cone Sul da América ${ }^{76}$.

A partir de conceitos políticos é possível revisitar o ideário e a trajetória de representantes de grupos liberais da cultura política como Bernardino Rivadavia, José Gervásio Artigas e João Soares Lisboa. Autores, que se debruçam sobre a História dos Conceitos na Ibero-América, constatam que o termo liberal poderia "cobijar a la vez un conjunto de principios doctrinalmente 'avanzados' y unos comportamientos nada violentos y altamente respetuosos con la tradición y con la historia nacional, al menos hasta el trienio 1820-1823 [...]"77. Esta polissemia contribuiu para a apropriação sincrônica e diacrônica do termo com a finalidade de valorizar ou desprestigiar os agentes sociais que se intitulavam liberais ou que assim haviam sido. No Rio da Prata e na Banda Oriental, o termo liberal tinha um sentido político-moral, mas também dizia respeito à oposição feita ao despotismo e tirania pela afirmação da liberdade e igualdade, desenvolvida na defesa da institucionalização de um regime representativo, constitucional e republicano ${ }^{78}$. Apesar desta associação, a análise do termo aponta justamente para a diversidade de significados, caminhos políticos e projetos de Estado nacional que, sob esta denominação, poderiam ser defendidos pelos agentes históricos. Neste sentido, poderia se imaginar o compartilhamento de experiências entre as recentes repúblicas hispano-americanas e o Brasil, mostrando a complexidade e convivência de identidades múltiplas, fragmentadas e provisórias e a possível convivência entre o regime monárquico e princípios, legitimidades ou linguagens republicanas sob o signo de um governo representativo ${ }^{79}$.

\section{O exílio como mecanismo da política liberal}

Dois dias antes da sua saída para o Rio de Janeiro, Correia da Câmara informava que "se despedia o impostor Lisboa dizendo ter sido chamado por Sua Majestade Imperial para a Corte do Rio de Janeiro". O Cônsul acreditava que Soares Lisboa, o "incendiário sans-culotte", partiria em um dos "navios Williams e Retrive[,] um para Gilbratar[,] outro para Liverpool", pois, segundo ele, estes seriam destinos comuns dos exilados ${ }^{80}$. Explicava que a partida de Soares Lisboa era motivada pela esperança em uma "contra revolução" realizada a partir de uma "porção de Deputados" do "Congresso do Brasil", o que concluíra com base em "Sátiras, Libelos infamantes e grosseiros Pasquins publicados e impressos em Montevidéu e Buenos Aires de então a esta parte, contra S. M. o Imperador, e o nosso atual sistema [Monárquico]" ${ }^{p 1}$.

\footnotetext{
76 Pereira de Brito Fonseca, 2016: 12-15 e 22-23.

77 Fernández Sebastián, 2009: 707.

78 Ibidem: 706; Wasserman, 2009 e 2010.

79 Berbel, 1999; Chiaramonte, 1997; Dolhnikoff, 2005, 2009; Jancsó - Pimenta, 2000.

80 Correspondência do cônsul do Brasil em Buenos Aires, Antônio Manuel Correia da Câmara (1822-1823). Colônia, 28-I-1823. AHI, estante 205, prateleira 02, maço 14.

81 Correspondência do cônsul do Brasil em Buenos Aires, Antônio Manuel Correia da Câmara (1822-1823). Rio de Janeiro, 16-IV-1823. AHI, estante 205, prateleira 02, maço 14.
} 
Neste sentido, a restrição do poder do rei, defendida por João Soares Lisboa, junto à atribuição ilimitada de poder ao Legislativo, era lida pelo Cônsul como um estratagema dos exilados para dominarem a política do Império e, a partir da Assembleia Legislativa, implementarem a república no Brasil. Em fevereiro de 1823, logo após seu retorno de Buenos Aires ao Rio de Janeiro, João Soares Lisboa foi encarcerado por ordem do Ministério para responder à devassa, na qual era réu. Do cárcere, recorreu de sua prisão aos deputados, reunidos na Assembleia Legislativa do Brasil, e retomou a publicação do Correio do Rio de Janeiro de maio de 1823 até novembro do mesmo ano. Suas edições eram marcadas por sua experiência de exílio em Buenos Aires, pela dramaticidade da situação de cárcere e radicalização de suas ideias.

Em relação aos modos de governar na monarquia constitucional, nestas edições, formulava com mais clareza as liberdades cívicas e políticas e as virtudes morais dos cidadãos e do Imperador, e defendia restrições ao poder Executivo. Estas publicações ratificavam sua crença na lei como a autoridade suprema na monarquia e que solucionaria as arbitrariedades e ilegalidades dos poderes auferidos às liberdades dos concidadãos. Ademais, suas publicações apresentavam e tratavam, em profundidade, as regulamentações a respeito de liberdades e direitos políticos e civis, demonstrando sua crença de que o novo pacto constitucional fundaria um governo com um espaço cívico que seria normatizado e regularia as relações entre os cidadãos e os poderes da monarquia. Neste sentido, apresentava dispositivos como a responsabilização dos ministros e o controle da magistratura, afinal, considerava-se uma de suas vítimas ${ }^{82}$.

As investidas finais do Cônsul Correia da Câmara contra os exilados foram feitas no Rio de Janeiro, no ano de 1823, quando testemunhou na bonifácia. Em relação a João Soares Lisboa, o testemunho de Correia da Câmara foi decisivo para sua condenação. As mesmas acusações que foram desmentidas para Joaquim Gonçalves Ledo recaíram sobre o redator do Correio do Rio de Janeiro e foram comprovadas pelo Cônsul através de uma carta copiada da original, que corria em Buenos Aires ${ }^{83}$. Sobre a correspondência, João Soares Lisboa confessou que escrevera de próprio punho a Joaquim Rodrigues da Costa Simões, Alferes do Batalhão de Caçadores, na Colônia, e "que tinha relações em Buenos Aires com alguns desses espanhóis que a testemunha [Correia da Câmara] chama[va] de inimigos do Brasil [...]"

Assim, no caso de João Soares Lisboa, o Cônsul forneceu o "corpo de delito" do crime, provando que incitava as tropas contra o governo do Rio de Janeiro, o que foi lido como parte de um "conluio republicano". Além disto, quando Soares Lisboa confessou sua relação com "espanhóis", tornou plausíveis as acusações de que teria se aliado aos rebeldes de Montevidéu no exílio, lá negociado letras de câmbio e armas e prejudicado o abastecimento de munição, armas e víveres às tropas do Brasil, enviados do Rio de Janeiro. Este era um ponto delicado da geopolítica do extremo sul do Império no combate, contra as tropas portuguesas, pela manutenção de territórios e pelo reconhecimento da independência. Segundo essas acusações, Soares Lisboa agia contra a estratégia das tropas do Brasil que, com o corte do fornecimento de víveres e soldo, pretendiam isolar e enfraquecer as tropas portuguesas instaladas em Montevidéu. Neste momento, Soares Lisboa calculou mal seu prestígio e reconhecimento

\footnotetext{
Ferreira, 2017: 262-294.

83 Correspondência do cônsul do Brasil em Buenos Aires, Antônio Manuel Correia da Câmara (1822-1823). Rio de Janeiro, 07-V-1823. AHI, estante 205, prateleira 02, maço 14.

${ }^{84}$ Schiavinatto - Ferreira, 2014b: 343.
} 
na Corte e subestimou o efeito negativo que sua confirmação de relacionamento com os "espanhóis" teria. De toda forma, a apresentação da carta por Correia da Câmara o deixou sem escapatória, a não ser se justificar ao público, o que fez nas publicações do Correio do Rio de Janeiro de 1823, escolhendo a imprensa como lugar de defesa.

Assim, foi condenado por se aliar a negociantes de Montevidéu e a rebeldes das tropas brasileiras, e por ter instigado e organizado um possível movimento armado contra o Imperador. Isto evidencia a revolta armada como um marcador do limite de tolerância do governo em relação à oposição ${ }^{85}$. Além da carta fornecida por Correia da Câmara, o silêncio sobre a impressão de libelos contra D. Pedro I e o governo do Império do Brasil -principalmente o mais famoso, "D. Ramon, Primeiro sem Segundo"- somado o título do libelo -imediatamente associado à sua consagrada frase publicada no Correio do Rio de Janeiro, "Eis o Pedro $1^{\circ}$ sem $2^{\circ "}$ - ratificava a autoria de Soares Lisboa ${ }^{86}$. Ademais, as publicações da "parte segunda" do Correio do Rio de Janeiro, em 1823, também serviram como prova de que desobedecera à ordem do Imperador, dada em 1822, para que encerrasse o periódico e se exilasse do Brasil.

Sobre a veracidade das informações do testemunho de Correia da Câmara, devese considerar o seu esforço em valorizar suas estratégias e serviço como Cônsul, o que resultou em uma narrativa dramática e exagerada, dando margem, inclusive, a que esta fosse colocada em dúvida: "se jurou falso a respeito deste [Joaquim Gonçalves Ledo], como pode ser acreditada a respeito do Redator do Correio?". Entretanto, Soares Lisboa, em seu testemunho na devassa, não negou as acusações, conferindo autenticidade às denúncias e à prova crime apresentadas pelo Cônsul ${ }^{87}$.

\section{Considerações Finais}

Em 5 de julho de 1823, João Soares Lisboa foi o único réu condenado pela bonifácia a uma pena de dez anos de prisão e ao pagamento de cem mil réis referentes às custas do processo. Recorreu da sentença, que, em 29 de julho, por ordem do Imperador, foi convertida a um emolumento de 50 mil réis e oito anos de exílio do Brasil ${ }^{88}$. João Soares Lisboa reagiu, publicando no Correio do Rio de Janeiro a defesa esquemática contra sua condenação, o que colocou em dúvida a absolvição dos outros réus. Neste ponto, apresentou sua versão do que fora o exílio em Buenos Aires, contradizendo as acusações apresentadas pelo Cônsul Câmara em seu testemunho na bonifácia. De acordo com Cecília Helena de Salles Oliveira, por destoar da absolvição dos outros réus, inclusive de Joaquim Gonçalves Ledo, seu companheiro de exílio em Buenos Aires, esta condenação marcaria a rearticulação do jogo político, desfazendo a aliança entre estes liberais e João Soares Lisboa, na Corte do Rio de Janeiro. O rompimento desta associação, em 1823, possibilitou aos absolvidos na bonifácia uma longa carreira ao lado de D. Pedro I e constituiu um ponto de viragem na política do Império ${ }^{89}$.

O exílio tornava-se, assim, um mecanismo de articulação política, que possibilitava que o exilado se inserisse em outros círculos de sociabilidades e rearranjasse alianças que lhe permitiriam retornar a posições privilegiadas de poder, muitas

\footnotetext{
85 Ibidem: 341-344; Ferreira, 2017: 262-294; Salles Oliveira, 1999: 299

86 Correio do Rio de Janeiro, $n^{\circ}$ 157, 19-X-1822, 697.

87 Schiavinatto - Ferreira, 2014b: 343.

88 Correio do Rio de Janeiro, $\mathrm{n}^{\mathrm{o}}$ 13, 31-VII-1823, 60.

89 Salles Oliveira, 1999: 294-300.
} 
vezes, ao lado de seus antigos opositores. O exílio era peça fundamental para o processamento da política. Em 1822, na consolidação da ordem constitucional com a Assembleia Legislativa do Brasil, fechada por D. Pedro I, em novembro de 1823, o exílio voltou a ser fundamental, agora para a absolvição dos réus da devassa por "conluio republicano" - com exceção de Soares Lisboa. Finalmente, também foi um dos elementos que propiciaram a convergência dos exilados em torno da defesa da Carta outorgada em 1824, contribuindo, além disto, para que, a partir desse momento, ocupassem papéis privilegiados na política do Império.

\section{Referências Bibliográficas}

Alegre, Aquiles Porto. Homens ilustres do Rio Grande do Sul. Porto Alegre: ERUS, 1981.

Alexandre, Valentim. Os sentidos do império. Questão nacional e questão colonial na crise do Antigo Regime português. Porto: Afrontamento, 1993.

Berbel, Márcia Regina. A nação como artefato: deputados do Brasil nas Cortes Portuguesas, 1821-1822. São Paulo: Hucitec, 1999.

Buchbinder, Pablo. "Caudillos y caudillismo: una perspectiva historiográfica”. En Caudillismos rioplatenses. Nuevas miradas a un viejo problema, organizado por Goldman, Noemí - Salvatore, Ricardo. Buenos Aires: Eudeba, 2005, 31-50.

Camargo, Antônio Eleutério De. "Biografia dos brasileiros ilustres: O conselheiro Antônio Manuel Correia da Câmara". Revista do IHGB, vol. 54 (1877), 505-506.

Carvalho dos Santos, Maria Helena. "Imprensa periódica clandestina no século XIX: 'O Portuguez' e a Constituição". Análise Social, no 61-62 (1980), 429-445.

Chiaramonte, José Carlos. Ciudades, provincias, Estados: Orígenes de la Nación Argentina (1800-1846). Buenos Aires: Ariel Historia - Biblioteca del Pensamiento Argentino, 1997.

Dolhnikoff, Miriam. O pacto imperial: origens do federalismo no Brasil do século XIX. São Paulo: Globo, 2005.

Fernández Sebastián, Javier (dir.). Diccionario político y social del mundo iberoamericano. La era de las revoluciones, 1750-1850. Madrid: Fundación Carolina - Sociedad Estatal de Conmemoraciones Culturales/Centro de Estudios Políticos y Constitucionales, 2009.

- Diccionario político y social del mundo iberoamericano. La era de las revoluciones, 1750-1850. Madrid: Centro de Estudios Políticos y Constitucionales - Universidad del País Vasco, 2014

Ferreira, Fábio. “O general Lecor, os voluntários reais e os conflitos pela independência do Brasil na Cisplatina (1822-1824)". Doutorado em História, Universidade Federal Fluminense, 2012.

Ferreira, Paula Botafogo Caricchio. "O princípio da moderação e a condenação de João Soares Lisboa na bonifácia: a interpretação de Mello Moraes na obra 'A Independência e o Império do Brasil' (1877)". En O oitocentos sobre novas perspectivas, organizado por Ribeiro, Gladys Sabina - Martins, Ismênia de Lima - Ferreira, Tânia Bessone da Cruz. São Paulo: Alameda, 2014, 253-274.

— "Negócios, impressos e política: a trajetória pública de João Soares Lisboa (1800-1824)". Doutorado em História, Universidade Estadual de Campinas, 2017.

- "Civique de Gastine (1793-1822) no Correio do Rio de Janeiro: Pacto Colonial, Economia Política e as Independências da América”. Estudos Ibero-Americanos, vol. 46, nº 2 (2020). Disponible em https://revistaseletronicas.pucrs.br/ojs/index.php/iberoamericana/ article/view/35177/26203. 
Figueira de Mello, Jeronymo de A. "A correspondência do Barão Wenzel de Mareschal (Agente diplomático da Áustria no Brasil, de 1821 a 1831)". Revista do IHGB, tomo 80 (1916), 9-48.

Frega, Ana. "La virtud y el poder. La soberanía particular de los pueblos en el proyecto artiguista”. En Caudillismos rioplatenses. Nuevas miradas a un viejo problema, organizado por Goldman, Noemí - Salvatore, Ricardo. Buenos Aires: Eudeba, 2005, 101-133.

Goldman, Noemí - Salvatore, Ricardo (orgs). Caudillismos rioplatenses. Nuevas miradas a un viejo problema. Buenos Aires: Eudeba, 2005.

Goldman, Noemí. Lenguaje y revolución: conceptos políticos clave en el Río de la Plata, 1780-1850. Buenos Aires: Prometeo, 2008.

Guimarães, Argeu. Diccionario bio-bibliographico brasileiro: de diplomacia, politica, externa e direito internacional. Rio de Janeiro: Edição do Autor, 1938.

Halperín Donghi,Tulio. "Mitre e a formulação de uma história nacional para a Argentina". Estudos Avançados, vol. 8, nº 20 (1994), 199-214.

- El espejo de la historia: problemas argentinos y perspectivas hispanoamericanas. Buenos Aires: Editorial Sudamericana, 1998.

— "Capítulo 2: La crisis de independencia". En Historia contemporánea de América Latina. Madrid: Alianza Editorial, 2005, 78-135.

- Revolução e Guerra. Formação de uma elite dirigente na Argentina criolla. São Paulo: Hucitec, 2015.

Jancsó, István (coord.). Cronologia de história do Brasil monárquico: 1808-1889. São Paulo: Humanitas/FFLCH/USP, 2000.

Jancsó, István - Pimenta, João Paulo G. "Peças de um mosaico (ou apontamentos para o estudo da emergência da identidade nacional brasileira)". En Viagem incompleta: a experiência brasileira: 1500-2000, organizado por Mota, Carlos Guilherme. São Paulo: Senac, 2000, 127-175.

Kühn, Fábio. Breve História do Rio Grande do Sul. Porto Alegre: Leitura XXI, 2002.

Landgraf Piccolo, Helga Iracema. "O processo de independência numa região fronteiriça". En Independência: História e historiografia, organizado por Jancsó, István. São Paulo: Hucitec - FAPESP, 2005, 577-613.

Lynch, John. Caudillos en hispanoamérica, 1800-1850. Madrid: MAPFRE, 1993.

Mattoso, José (Org.). História de Portugal: O liberalismo (1807-1890). Lisboa: Editorial Estampa, 1993.

Myers, Jorge. Orden y virtud: el discurso republicano en el régimen rosista. Buenos Aires: Universidad Nacional de Quilmes, 1995.

- Identidades porteñas. "El discurso ilustrado en torno a la nación y el rol de la prensa: El Argos de Buenos Aires, 1821-1825”. En Construcciones impresas, panfletos, diarios y revistas en la formación de los estados nacionales en América Latina, organizado por Alonso, Paula. México: FCE, 2004, 39-63.

Neri de Campos Basile, Marcello Otávio. “O Império em construção: projetos de Brasil e ação política na Corte regencial”. Doutorado em História Social, Universidade Federal do Rio de Janeiro, 2004.

Pereira das Neves, Lúcia Maria Bastos. Corcundas e Constitucionais. A cultura política da independência (1820-1822). Rio de Janeiro: Faperj - Revan, 2003.

Pereira de Brito Fonseca, Silvia Carla. A ideia de república no império do Brasil: Rio de Janeiro e Pernambuco (1824-1834). Jundiaí: Paco Editorial, 2016.

Peres Costa, Wilma. "A Independência na historiografia brasileira". En Independência: história e historiografia, organizado por Jacsó, István. São Paulo: Hucitec, 2005, 53-118. 
Pimenta, João Paulo G. Estado e Nação no fim dos impérios ibéricos no Prata (1808-1828). São Paulo: Hucitec - FAPESP, 2002.

- A independência do Brasil e a experiência hispano-americana (1808-1822). São Paulo: Hucitec/FAPESP, 2015.

- Tempos e espaços das independências: a inserção do Brasil no mundo ocidental (c. 1780c. 1830). São Paulo: Entr[H]istória, 2017.

Salles Oliveira, Cecília Helena de. A astúcia liberal: relações de mercado e projetos políticos no Rio de Janeiro (1820-1824). São Paulo: USF, 1999.

Santos Alves, José Augusto dos. Ideologia e política na imprensa do exílio "O Portuguez" (1814-1826). Lisboa: Instituto Nacional de Investigação Científica - Centro de História da Cultura da Universidade Nova de Lisboa, 1992.

Schiavinatto, Iara. Pátria coroada. O Brasil como corpo político autônomo (1780-1831). São Paulo: Editora UNESP, 1999.

Schiavinatto, Iara - Ferreira, Paula Botafogo. “As rememorações da 'bonifácia': entre a devassa de 1822 e o Processo dos cidadãos de 1824”. R. IHGB, no 462 (jan./mar. 2014a), 201-238.

— "As rememorações da "bonifácia": entre a devassa de 1822 e o Processo dos cidadãos de 1824 - (2 $2^{\mathrm{a}}$ parte). VOLUME II”. R. IHGB, nº 463 (abr./jun. 2014b), 287-348.

Schultz, Kirsten. Versalhes tropical: império, monarquia e a Corte real portuguesa no Rio de Janeiro, 1808-1821. Rio de Janeiro: Civilização Brasileira, 2008.

Tengarrinha, José. Nova história da imprensa portuguesa: das origens a 1865. Lisboa: Temas e debates, 2013.

Ternavasio, Marcela. Historia de la Argentina 1806-1852. Buenos Aires: Siglo Veintiuno Editores, 2009.

Varnhagen, Francisco Adolfo de. História da independência do Brasil: até ao reconhecimento pela antiga metrópole, compreendendo, separadamente, a dos sucessos ocorridos em algumas províncias até essa data. Brasília: Senado Federal, 2010.

Wasserman, Fabio. “Argentina - Río de la Plata". En Diccionario político y social del mundo iberoamericano. La era de las revoluciones, 1750-1850, editado por Fernández Sebastián, Javier. Madrid: Fundación Carolina - Sociedad Estatal de Conmemoraciones Culturales - Centro de Estudios Políticos y Constitucionales, 2009, 732-743.

— "Revolución y Nación en el Río de la Plata (1810-1860)". En La Construcción de la Nación Argentina. El rol de las fuerzas armadas. Debates históricos en el marco del Bicentenario (1810-2010), organizado por Moreno, Oscar. Buenos Aires: Ministerio de Defensa, 2010, 35-42.

Wiederspahn, Henrique Oscar. "Das guerras Cisplatinas às guerras contra Rózas e contra o Paraguai”. En Enciclopédia Rio Grandense, organizado por Becker, Klaus. Canoas: Editora Regional, 1956. 